\title{
THE EVOLUTION OF HEAT AND MOISTURE IN THE \\ RESPIRATORY TRACT DURING ANAESTHESIA \\ WITH A NON-REBREATHING SYSTEM
}

\author{
RAYNALd DÉRY, M.D., F.R.C.P.(c)
}

THREE MAJOR DISADVANTAGES are currently associated with non-rebreathing systems in anaesthesia. The first is the cost of discarding large amounts of expensive gases and vapours in the ambient atmosphere. The second, closely related to the first, is operating room pollution. ${ }^{1,2}$ The third is concerned with the potentially harmful effects of flushing the respiratory tract with desiccated gas mixtures. ${ }^{3,4}$

We can imagine, in theory, the threatening sequence associated with the inhalation of a dehydrated gas mixture, particularly when the air-conditioning facilities of the nasal passages are being by-passed. It can be assumed that the dry gases will reach the trachea still completely dry, at a temperature very much the same as room temperature. Consequently, the inspired gas mixture will take up moisture and heat from the tracheobronchial tree, leading to local hypothermia, poor ciliary activity, decreased water content of mucus, impaired mucus rheology and accumulation of viscid secretions. This may not be a serious handicap to anyone who can cough forcibly, but for the operative patient, whose power to cough is impaired, it may be disastrous.

The effects of dry anaesthetic gases on the tracheobronchial ciliated epithelium were recently described by Chalon, Loew and Malebranche. ${ }^{5}$ Having sampled the ciliated epithelium of the tracheobronchial tree from bronchial lavage, they noticed deciliation, loss of endplates and distortion and pyknosis of the nuclei. However, no measurements of the actual moisture in the tracheobronchial tree were done prior to sampling, so documentation on this aspect still remains very scant. The purpose of our work was to measure the heat and moisture pattern in the airways during clinical anaesthesia using a non-rebreathing system and to compare it with the semiclosed circle and normal patients at rest.

\section{Experimental Procedure}

Our measurements were obtained in the operating room during the course of uncomplicated anaesthesia in ten normal patients. The operations were lengthy, involving the abdomen or the limbs. Adults were preferred to children, and males to females, because the larynx could accept a wider bore tracheal tube. It was felt that our sampling devices would thus cause minimal disturbance of the geometric configuration of the airway.

Immediately following the induction of anaesthesia, the tracheal tube was connected with a non-rebreathing system, using Fink's valve as the basic directional

Department of Anaesthesia and Resuscitation, L'Hôtel-Dieu de Québec and Laval University. This study was presented at the C.A.S. annual meeting, June 1972, in Halifax, and was supported by M.R.C. grant No. MA 2968.

Canad. Anaesth. Soc. J., vol. 20, no. 3, May 1973 
device. Our Fink's valve was modified to permit the collection and analysis of expired air. Pulmonary ventilation was effected with a Bird Mark 4-Mark 7 assembly, delivering a tidal volume equal to one and a half times that of Radford's nomogram, at a frequency of 10 per minute. This rather large tidal volume insured that the reading of the temperature sensor inside the airway had come to its full deflection before the beginning of the next respiratory phase. This was demonstrated on the record by the appearance of a plateau at both ends of the temperature shifts from inspiration to expiration.

We were particularly careful to eliminate sources of water contamination which could produce artifactual results. The Fink's valve was dried with oxygen before use. The concertina bag and the outlet circuit of the Bird Mark 4 were dried with desiccated gas for an hour before the procedure. New corrugated tubes were used for each experiment.

A delay of 30 minutes was allowed, to reach an experimental steady state. Then, following methods previously described, we measured temperature and moisture at a sequence of $5 \mathrm{~cm}$ along the airway, from the valve to bronchial divisions of the third generation. ${ }^{6}$

In essence, a fast-response temperature sensor was inserted at measured distances within the respiratory tract. Exact distances were measured by attaching the thermistor to a peridural catheter. The presence of this temperature sensor even at very low sites down the airway induced no modification of either frequency or tidal volume.

After monitoring the temperature at one particular site, the thermistor was withdrawn and the sampling tube of the dew-point hygrometer was inserted to the same position. The procedure for sampling the inspired gas mixture was in fact auto-sampling. A representative amount of inspired air ( $30 \mathrm{ml}$ per respiration) was circulated through the hygrometer due to the pressure gradient generated by the respirator. To allow for clearing of deadspace, we avoided sampling during the first part of each respiratory phase. Sampling was interrupted manually during the expiratory phase. This first series of measurements provided us with readings of the average relative humidity of inspired gases.

We then did fractional sampling of the moisture content of the inspired gas mixture in the first third, the middle, and the last part of each tidal volume. This fractionation was monitored with a Wright ventilometer set on the inspiratory limb of the system.

The sampling procedures were then repeated on the expired gas mixture, after which the non-rebreathing system was exchanged for the standard semiclosed circuit, using the Ohio number 20 sodalime absorber and the $\mathrm{Y}$-swivel valve. After a period of 15 minutes for adjustment to the change of technique, another series of temperature and humidity measurements were obtained, using the same ventilatory pattern. In this way, the patient became the point of reference when comparing the two techniques.

\section{Results}

Measurements of moisture during the expiratory phase repeatedly displayed saturation at all points along the airway. On its way out of the airway, the expired gas mixture underwent a quasi-linear decrease in temperature. The inflection of 




FIgure 1. Temperature and moisture in the expired gas mixture during anaesthesia with the non-rebreathing system.

the curve at its distal end was attributed to variations in the cross-section of the lower airway. The steeper slope of the curve at the beginning shows heat transfer from the ambient atmosphere to the valve and the outer half of the tracheal tube (Figure 1).

During the inspiratory phase, the originally cool and dry gas mixture underwent a conspicuous gain in temperature which averaged one degree centigrade per $5 \mathrm{~cm}$ of airway above the carina. Then sharp increments averaging 2 to 3 degrees per 5 $\mathrm{cm}$ of airway were disclosed in the lower respiratory tract. This was also attributed 
DÉRY: HEAT AND MOISTURE IN RESPIRATORY TRACT

TEMPERATURE OF THE INSPIRED GAS MIXTURE

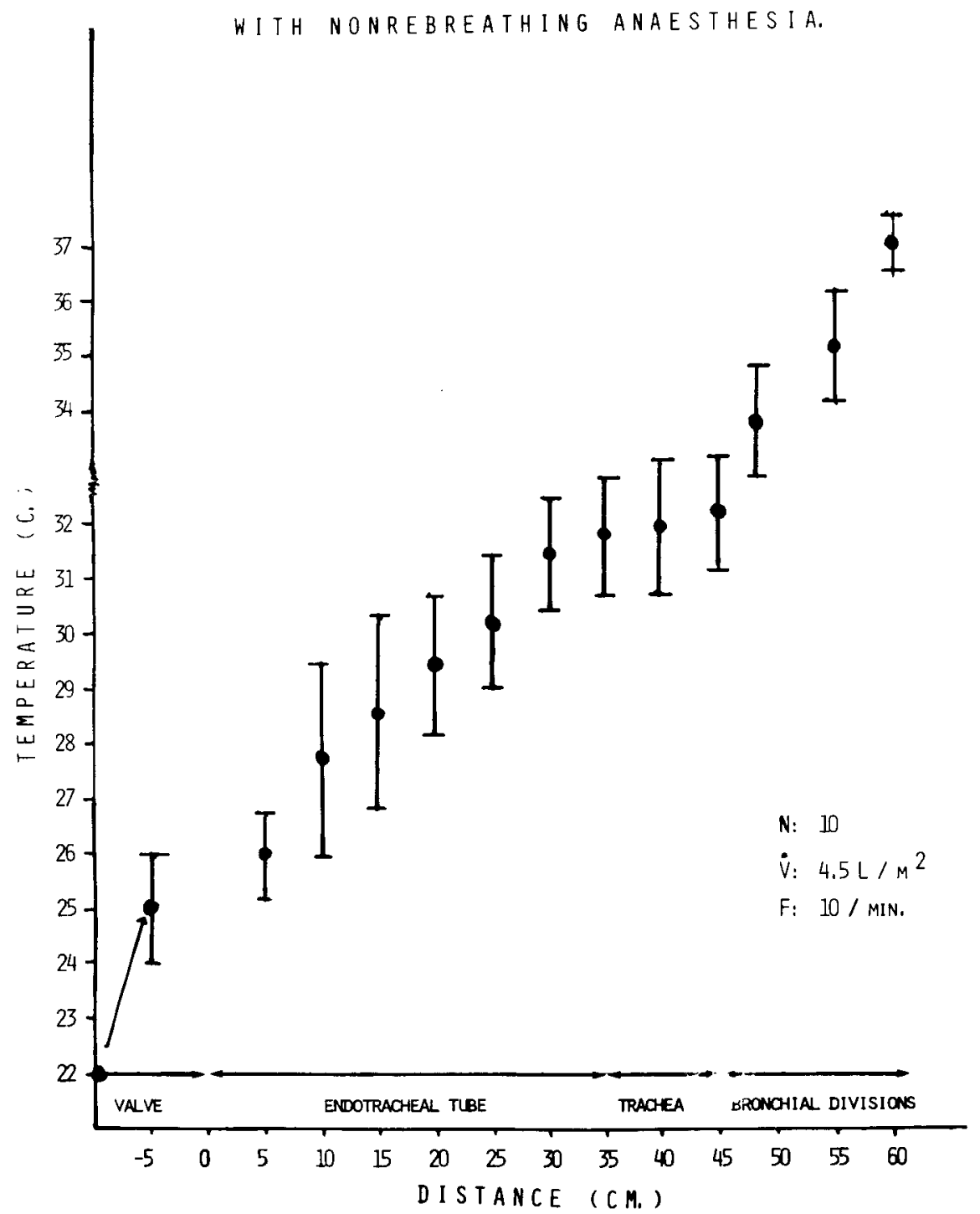

FIGURE 2. Temperature of the inspired gas mixture with non-rebreathing anaesthesia.

to the sudden increase in the cross-section available for heat evolution each time a segment of the airway gave birth to a new generation of dichotomic divisions. Body isothermia was indicated by the absence of temperature variations between inspiration and expiration. It was noted at relatively distant points, usually $15 \mathrm{~cm}$ below the carina, and probably in bronchial divisions of the third generation (Figure 2).

The evolution of the relative humidity during non-rebreathing anaesthesia is shown in Table I and summarized in Figure 3. It was characterized by a con- 


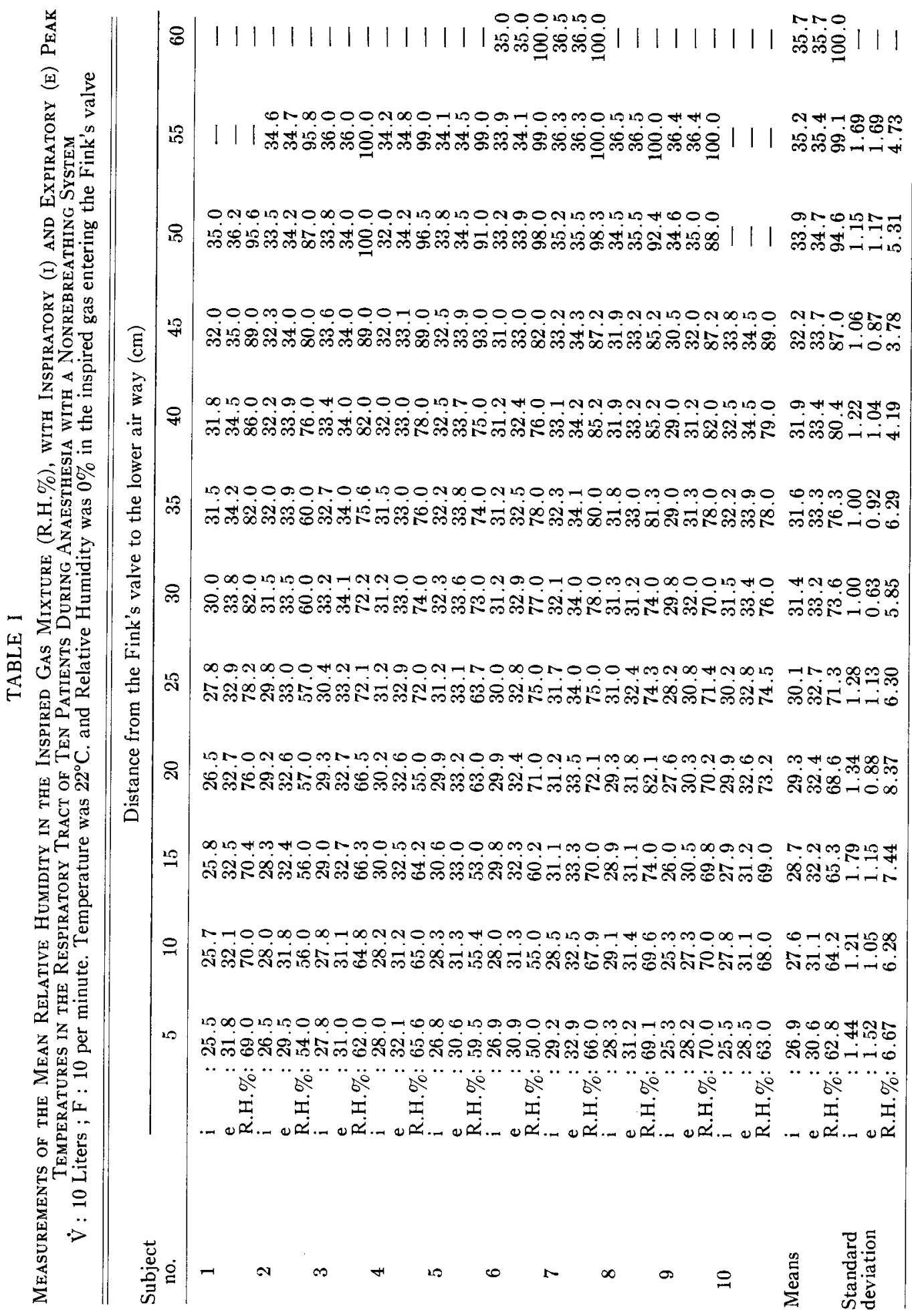


AVERAGE MOISTURE CONTENT DURING

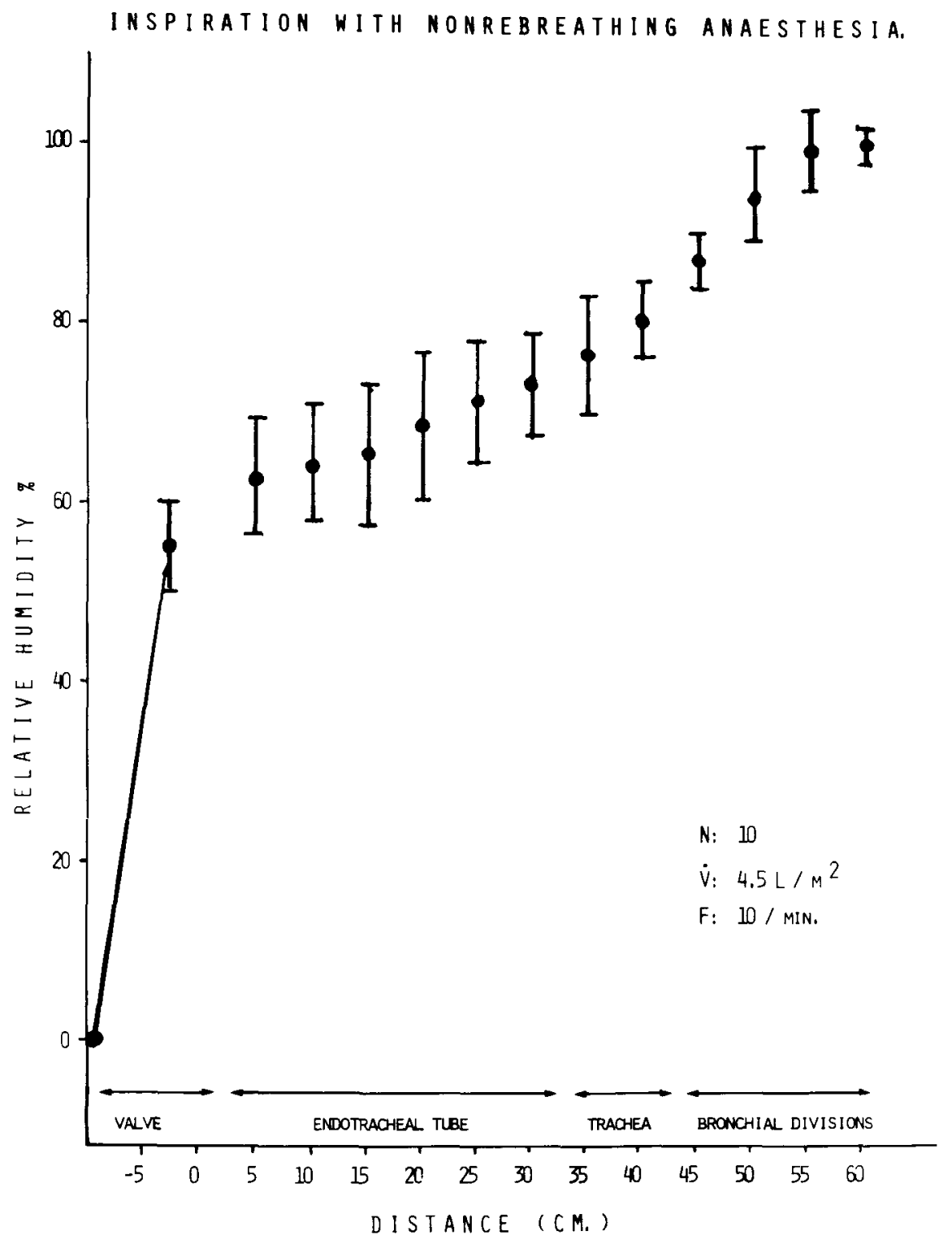

FIGURE 3. Average moisture content during inspiration with non-rebreathing anaesthesia.

spicuous increase from 0 per cent to 55 per cent at the outlet of the Fink's valve. It rose to 60 per cent at the beginning of the tracheal tube, and reached an average of 75 per cent at its tracheal end. It read 80 per cent in the trachea, 90 per cent in the main bronchi, and 100 per cent was attained in the lobar divisions. Isothermic saturation, i.e. 100 per cent relative humidity at body temperature was reached at what we called the Isothermic Saturation Boundary, I.S.B., approximately $15 \mathrm{~cm}$ below the carina. The I.S.B., as previously described, could be shifted by changing the tidal volume. ${ }^{7}$ 


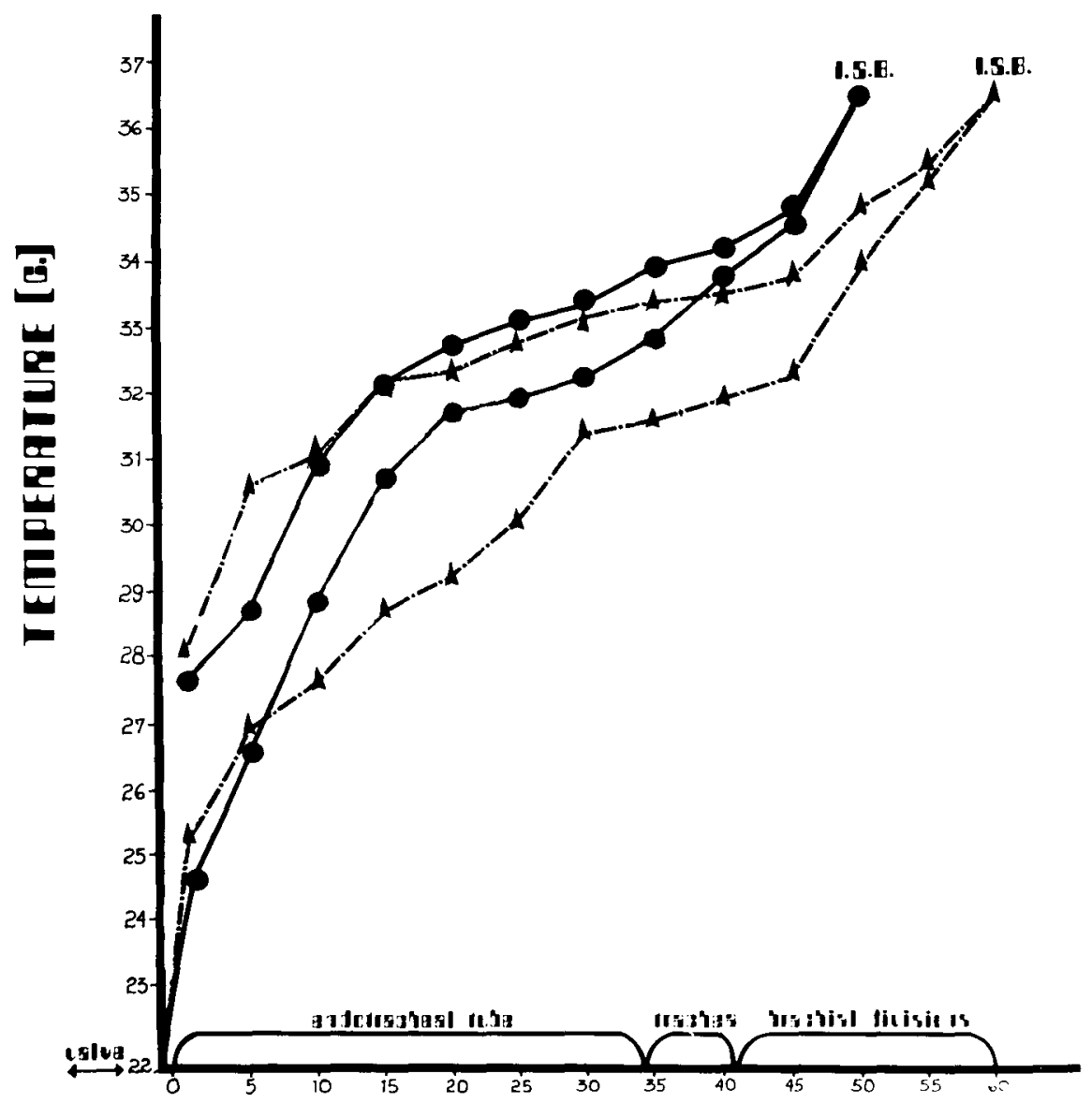

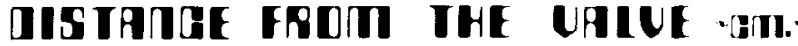

Figure 4. Comparative patterns of heat evolution in the airway between anaesthesia with the semiclosed system (Points and the white area between them) and anaesthesia with the nonrebreathing technique (Triangles and the area between them). I.S.B. = isothermic saturation boundary, 100 per cent relative humidity at body temperature.

The difference in the pattern of heat gain and heat transfer between the nonrebreathing and semiclosed techniques of anaesthesia is depicted in Figure 4. It is readily apparent that heat gain during inspiration was definitely slower with the non-rebreathing system. With this technique, a wider gap also occurred between the inspiratory and expiratory temperatures at the same sampling point. This temperature difference took place predominantly at the expense of the inspired gas temperature, as a result of energy expenditure for greater evaporative work. It is of interest to note how the I.S.B. fell at a lower point with the non-rebreathing system. 
DÉRY: HEAT AND MOISTURE IN RESPIRATORY TRACT

COMPARATIVE DATA ON THE MOISTURE

CONTENT OF INSPIRED GAS MIXTURE.

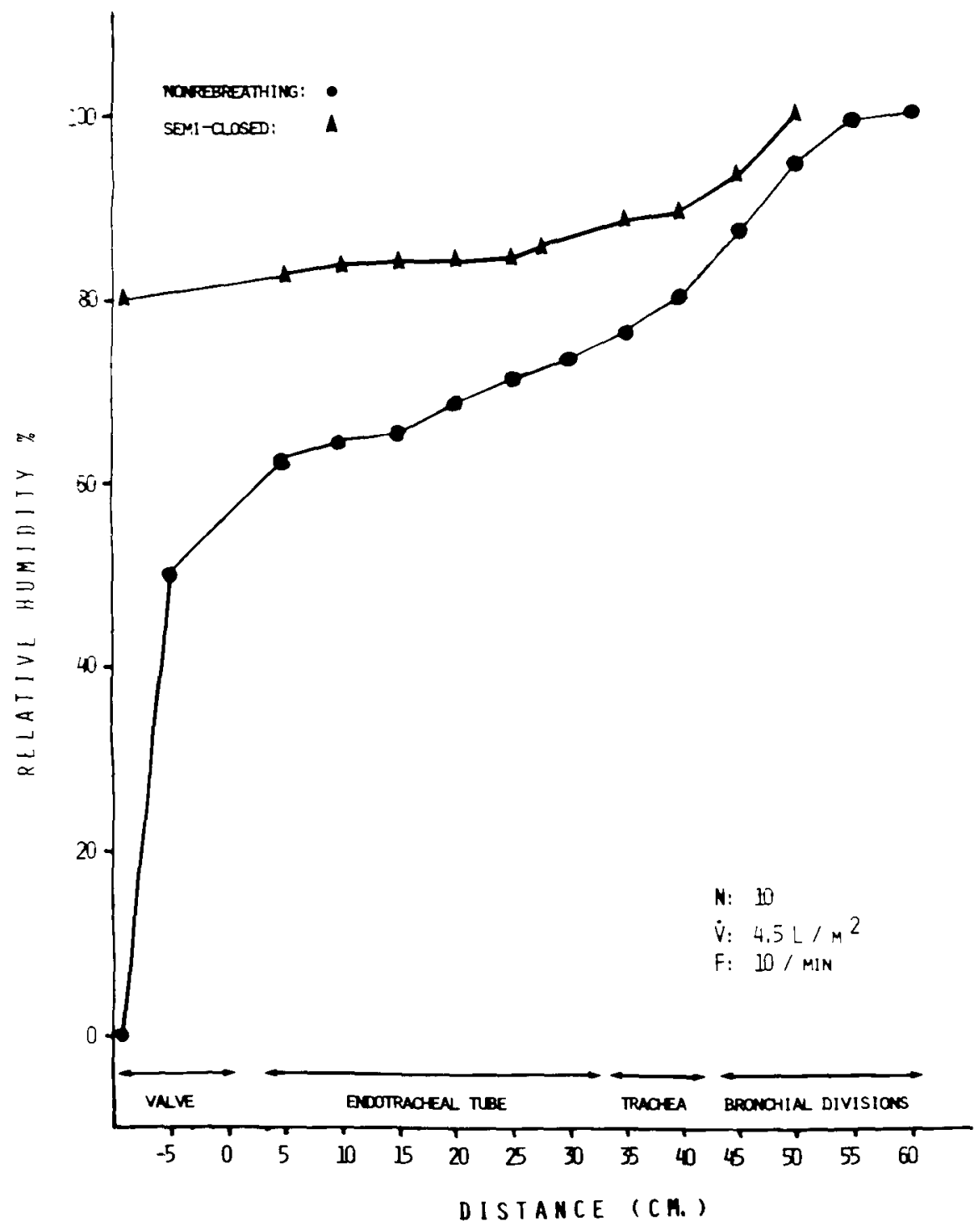

FIGUnE 5. Comparative data on the moisture content of the inspired gas mixture. The results of relative humidity with the non-rebreathing system are illustrated with points, whereas those with the semiclosed circle are represented by triangles.

Figure 5 compares the readings of relative humidity obtained with the two techniques. Although quite significant in the valve and in the tracheal tube, the difference tends to minimize in the tracheobronchial tree. Of utmost importance, in view of Dalhamm's work, is the fact that the relative humidity never fell below 70 per cent in the trachea with either technique. ${ }^{8}$ 


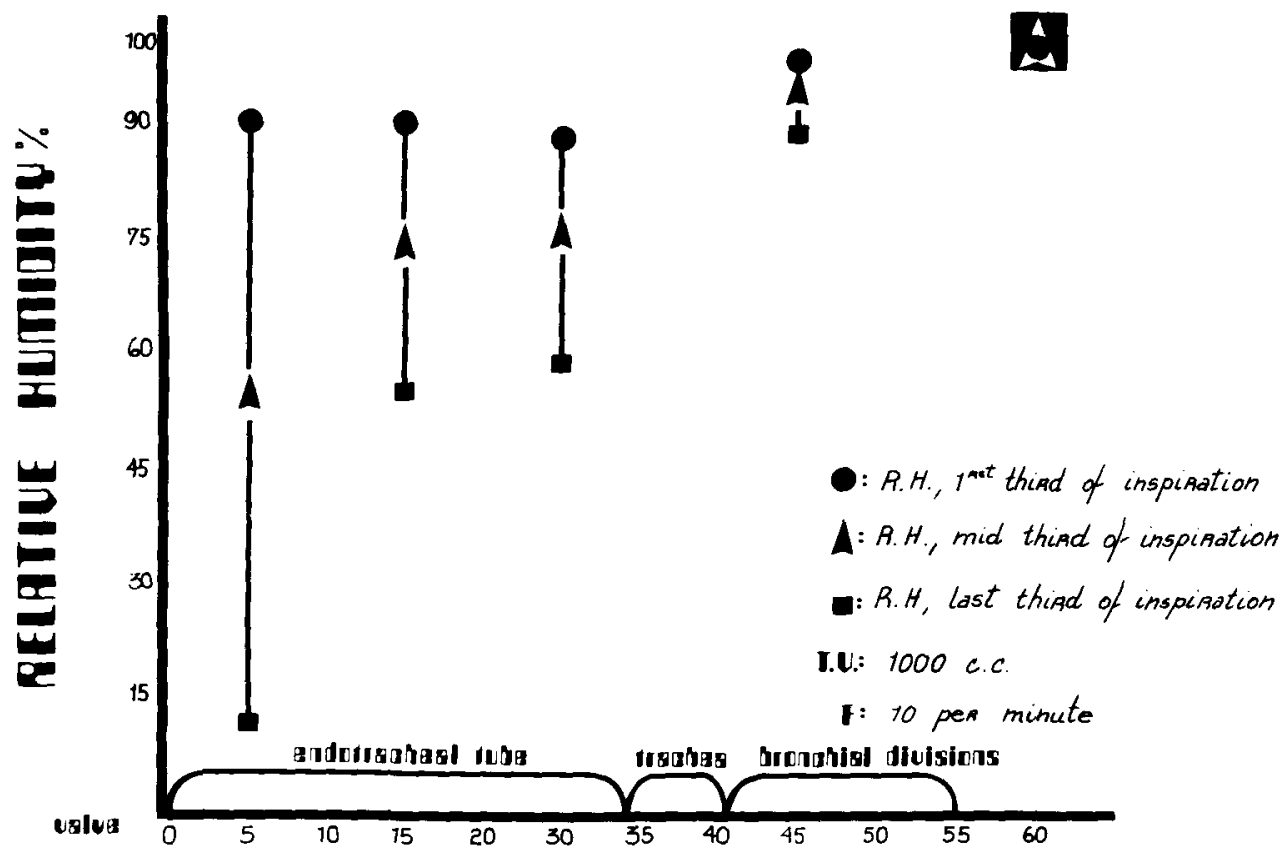

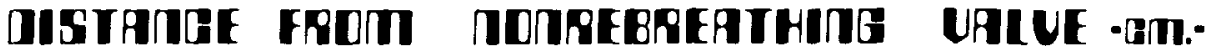

FIGURE 6. Results of the relative humidity per cent obtained on fractions of the inspired tidal volume, during anaesthesia with the non-rebreathing system.

So far we have dealt with measurements of the mean relative humidity obtained by sampling the whole inspiration. Figure 6 illustrates the results of the fractional analysis of the inspired gas mixture. In the upper airway the readings varied greatly from the first fraction of an inspiration to the last part of it. Actually, the relative humidity in the Fink's valve evolved along an exponential curve from near saturation initially to near desiccation at the end of each inspiration. The scatter in the results progressively decreased along the tracheal tube, more water being available for evaporation. For all intents and purposes, the relative humidity of the inspiration was homogeneous in the trachea. With the semiclosed circle, this phenomenon, albeit present, is of minor importance due to the fact that the inspired gas mixture enters the airway already charged with 80 per cent relative humidity.

\section{Discussion}

The protection of the respiratory function during anaesthesia includes the administration of a controlled atmosphere which ideally should mimic the normal physiological state. But from the beginning, we are faced with the problem of being quite in the dark about the normal climatic conditions which prevail in the lower airway. Perwitzschky, ${ }^{9}$ Cramer $^{10}$ and Cole ${ }^{11}$ carried out extensive studies of the evolution of temperature and moisture in the upper respiratory tract, parti- 
cularly in the nasopharynx, and provided us with some data obtained in laryngectomized patients.

Motivated by the necessity to compare our results with controls, we measured the temperature and relative humidity in the upper and lower airways of three patients at rest and breathing ambient air through the nose. These patients were wearing small tracheostomy canulae which were usually occluded by a cork. These tracheostomies had been performed three weeks previously as a prophylactic measure before radio-active cobalt therapy to the pharynx. The treatments were completed a week before, and the patients were ready to leave the hospital. Our sampling of temperature and moisture was achieved from the nose, the nasopharynx and through the occluded stoma from the lower airway. These measurements disclosed the following results. In a conscious man breathing room air at a relative humidity of 45 per cent, the inspired air reached a relative humidity of 65 per cent at a temperature of $32^{\circ} \mathrm{C}$. in the nasopharynx; 69.5 per cent at the inlet of the larynx, with a temperature of $33.2^{\circ} \mathrm{C}$.; 88 per cent at a temperature of $35.3^{\circ} \mathrm{C}$., 9 centimeters below the vocal cords; 95 per cent at the carina, where a temperature of $36.8^{\circ}$ was found; and 100 per cent at body temperature 5 centimeters below the carina (Figure 7).

We can compare these results at a glance with those already obtained during anaesthesia. A major feature to be emphasized is the isothermic saturation boundary shifting from one point to another, being highest in the normal man at rest, intermediate during anaesthesia with the semiclosed system, and lowest with the non-rebreathing technique. From its native site at or near the carina in the man breathing through his nose, it moves down to $10 \mathrm{~cm}$ below the carina during anaesthesia with the semiclosed circle; it reaches its lowest point, $15 \mathrm{~cm}$ below the carina, during anaesthesia with a non-rebreathing system.

In trying to piece together the information so far obtained in terms of moisture gain during inspiration, precipitable water during expiration, moisture conservation and loss at different points of the airway, we could approach the concept of a water budget for the whole respiratory tract, indicating the part played by each component.

In the normal man breathing through his nose inspired moisture is provided as follows: 4 gm per hour are already present in the inspired air; $6 \mathrm{gm}$ are added through evapo-transpiration in the nasal passages. The pharynx and larynx provide $7 \mathrm{gm}$ per hour, to which the tracheobronchial tree adds $3.6 \mathrm{gm}$. The net debt of moisture per hour amounts to grossly $10 \mathrm{gm}$.

During anaesthesia with the semiclosed system, the major feature is the contribution of the soda-lime absorber as a humidifier.$^{12}$ It provides $9 \mathrm{gm}$ of water per hour, under the conditions of our experiments. Meanwhile, the lower airway has to provide only $1 \mathrm{gm}$ of water as transudate to insure isothermic saturation, since the valve and the tracheal tube saved $6.8 \mathrm{gm}$ through water conservation and evaporation. The net debt of moisture is therefore only $3.6 \mathrm{gm}$ per hour.

With the non-rebreathing system, 20 gm of water must be generated in the respiratory tract. Of these, $8.8 \mathrm{gm}$ are gained through recapture of condensed water from the valve and the tracheal tube, but $11.8 \mathrm{gm}$ must be provided as transudate through the tracheobronchial tree itself. The net debt of water amounts 


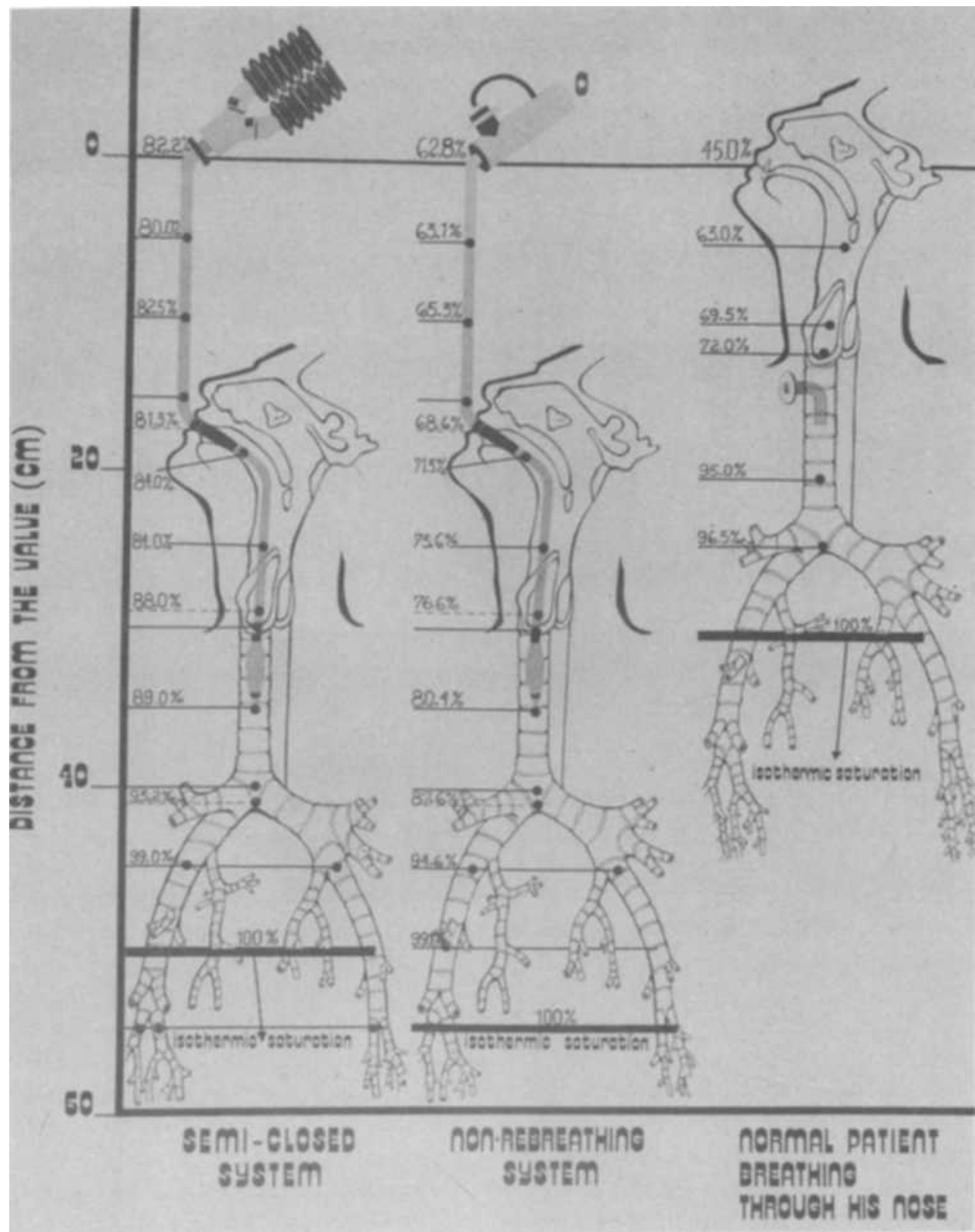

FIgURE 7. Schematic representation of the relative humidity at comparable sites in the airway, during anaesthesia with either the semi-closed system or the non-rebreathing system, and in the normal patient breathing ambient air through his nose.

to $12.7 \mathrm{gm}$, a figure definitely higher than that for the semiclosed circuit, but relatively close to that of a normal man at rest.

The non-rebreathing technique, owing to propitious gradients of the tension of water vapour and temperature, provides water conservation in the upper airway 
through alternating patterns of condensation and evaporation. It thus insures a mean relative humidity over 70 per cent in the trachea during inspiration. According to Dalhamm this would guarantee a normal environment for ciliary activity. ${ }^{8}$ Another feature of this technique is the maintenance of isothermic saturation within the functional residual capacity and the smaller airways.

On the other hand, during anaesthesia with a non-rebreathing system, the upper tracheobronchial tree has to transudate larger amounts of water than with any other technique. This peculiarity may eventually overcome the physiological limits of the mucosal cells, leading to cell dehydration, poor activation of ciliary pacemakers and, furthermore, modifying the hydrate bounds of the complex polymer mucus.

Our personal opinion is that the safety margin of this technique can easily be improved, as far as hygrometry is concerned, by the very simple procedure of passing the inflowing gases through a soda-lime absorber, which plays the role of a very efficient humidifier.

\section{SUMMARY}

The evolution of heat and moisture in the respiratory tract have been investigated both in the conscious subject at rest and in patients during anaesthesia with the non-rebreathing system.

The efficiency of moisture conservation provided by the artificial airways, nonrebreathing valve and tracheal tube mimics that of the upper airway in the conscious man. Total moisture debt is almost the same in both circumstances, reaching about $10 \mathrm{gm}$ per hour in the normal man at rest breathing through his nose, compared to an average loss of $12 \mathrm{gm}$ during anaesthesia with a non-rebreathing system. These results, added to those already described during anaesthesia with the semi-closed circle, strongly suggest that the factors regulating heat and moisture exchange in the airways, both normal and artificial, are mainly related to physics. Heat and moisture evolve along thermodynamic and hydrodynamic gradients, the mucus blanket and the artificial airways being the sites for heat transfer, water precipitation and evaporation.

With the non-rebreathing system, due to the physical limitation of the diabatic properties of the artificial airway, the balance between precipitable water during expiration and moisture gain during inspiration results in a debt of moisture which is dealt with by two mechanisms. The first is a downward shift of the isothermic saturation boundary, thus involving a larger area of the tracheobronchial tree in heat and moisture exchanges. The second is transpiration of water through the mucous membranes of the upper tracheobronchial tree. This phenomenon is maximal with the non-rebreathing system, amounting to nearly $12 \mathrm{gm}$ per hour in the adult. Eventually, the resulting dehydration and dysfunction of the epithelial cells in the upper tracheobronchial tree may well become a definite hazard. A prophylactic means, both simple and efficient, would be the addition of moisture to the inspired mixture by passing the inflowing dry gases through the soda-lime absorber, to which a new vocation would be added. 


\section{RÉSUMÉ}

Les multiples méfaits qu'on attribue sur des bases théoriques à l'administration endotrachéale de gaz secs semblent prévisibles, et comportent la déshydratation de la muqueuse respiratoire, la dysfonction muco-ciliaire et l'hypothermie locorégionale. Tout récemment, Chalon, Loew et Malebranche décrivaient les répercussions cellulaires de cette dessiccation : déciliation, distorsion cellulaire et pinocytose. ${ }^{5}$ Cependant, en l'absence de mesures directes de l'humidité et de la température qui prévalent dans l'arbre trachéo-bronchique lors de l'administration de gaz déshydratés, ces considérations et ces constatations risquent de demeurer spéculatives ou incomplètes.

Nous avons voulu, dans cette étude, remédier à cette carence en mesurant d'une façon séquencielle et comparative l'évolution de l'humidité et de la température dans les voies aériennes au cours de l'anesthésie en ventilation sans recyclage.

Nos résultats démontrent que les gaz inspiratoires, loin de demeurer secs jusqu'à la trachée, se chargent déjà, dès la valve directionnelle, de 55 pour cent d'humidité relative. Au fur et à mesure que l'air inspiré progresse dans l'airway, sa température et son humidité montent de pair. L'humidité relative atteint 75 pour cent au bout distal du tube endotrachéal, 80 pour cent dans la trachée et 90 pour cent à la carène. Le point de saturation isothermique, lieu où se retrouve 100 pour cent d'humidité relative à la température corporelle, se retrouve à environ 15 centimètres en bas de la bifurcation trachéale.

Ces constatations diffèrent très peu de celles décrites en cours d'anesthésie en circuit demi-fermé ${ }^{6}$ et se rapprochent étrangement de celles qui prévalent chez l'individu conscient qui respire à l'air libre. Quelques particularités méritent cependant d'être soulignées :

1. le point de saturation isothermique, situé aux environs de la carène chez l'individu conscient et respirant par le nez, s'abaisse de 10 centimètres lors de l'anesthésie en circuit demi-fermé, et de 15 centimètres au cours de l'anesthésie sans recyclage, le mélange inspiré étant à ce moment complètement déshydraté. 2. l'écart de température entre l'inspiration et l'expiration, en un point donné des voies aériennes, est plus important avec la méthode sans recyclage, traduisant des échanges hydriques, évaporation et condensation, plus importants.

3. la dette totale encourrue au bilan hydrique respiratoire se chiffre à trois grammes par heure en cours d'anesthésie en circuit demi-fermé; à 10 grammes par heure chez l'individu conscient respirant à l'air libre, et à 12 grammes/heure en cours d'anesthésie sans recyclage. On pourraît conclure d'emblée à une différence peu significative entre ces deux dernières situations. La différence est cependant majeure lorsqu'on étudie les composantes internes d'un tel bilan.

Fait capital à souligner, l'indivdu conscient respirant par le nez ne transsude qu'environ 3 grammes d'eau par heure au niveau de la trachée et de ses divisions bronchiques hautes, par suite de l'efficience thermodynamique et hydrodynamique maximale de ses voies aériennes supérieures à conserver l'eau d'expiration.

En cours d'anesthésie sans recyclage, l'administration de gaz secs sous-entend que l'individu doit générer 20 grammes d'eau par heure dans ses voies aériennes tant naturelles quartificielles. Or les propriétés thermodynamiques et hydrodynamiques des airways artificiels, même si elles s'apparentent à celles des voies 
aériennes naturelles, ont certaines limites inhérentes à leurs caractéristiques physiques, de sorte que l'arbre trachéo-bronchique doit transsuder environ 12 grammes d'eau par heure pour que soit atteinte éventuellement la saturation isothermique, si essentielle à la physiologie des structures de la capacité résiduelle fonctionnelle. Un tel effort de déshydratation de la part des cellules de recouvrement de la muqueuse de l'arbre trachéo-bronchique supérieur peut certes dépasser les limites physiologiques, conduisant à une dysfonction de ces cellules, sinon à leur dévitalisation.

C'est pourquoi nous jugeons opportun, au terme de cette étude, de recommander un apport exogène d'humidité à cette technique d'anesthésie où des gaz secs sont ventilés dans les voies aériennes, en l'absense de tout recyclage. Il est d'ailleurs facile d'y arriver en passant le flot des gaz inspiratoires dans le large canister de chaux sodée, dont nous avons antérieurement décrit l'efficacité à titre d'humidificateur.

\section{REFERENCES}

1. MCIntyre, J.W.R. \& RUSSEL, J.C. Removal and recovery of halothane and the methoxyflurane from waste anaesthetic vapours. Canad. Anaesth. Soc. J., 14: 333 (1967).

2. Davis, D.A. The operating room: an unhealthy environment. Modern Anaesthesia, Vol. 2. F.A. Davis, Co., Philadelphia (1968).

3. BuRton, J.D.K. Effects of dry anaesthetic gases on the respiratory mucous membrane. Lancet 1: 235 (1962).

4. Rashad, K.F., Wilson, D.M., Hurt, H.H., Jr., GrafF, T.D., \& Benson, D.W. Effect of humidification of anesthetic gases on static compliance. Anesth. Analg. 46: 127 (1967).

5. Chalon, J., Loew, D.A., \& Malebranche, J. Effects of dry anesthetic gases on tracheobronchial ciliated epithelium. Anesthesiology 37: 338 (1972).

6. Déry, R., Pelletier, J., Jacques, A., Clavet, M., \& Houde, J.J. Humidity in anesthesiology: III. Heat and moisture patterns in the respiratory tract during anaesthesia with the semiclosed system. Canad. Anaesth. Soc. J. 14: 287 (1967).

7. DÉRY, R. Humidity in anesthesiology: IV. Determination of the alveolar humidity and temperature in the dog. Canad. Anaesth. Soc. J. 18: 145 (1971).

8. Dalmamm, T. Mucous flow and ciliary activity in the tracheas of healthy rats and rats exposed to respiratory irritant gases. Acta Physiol. Scand. (Suppl. 123) 36: 14 (1956).

9. Perwitzschky, R. Temperature and moisture of air and air passages. Arch. Ohr. Nas., a. Kehlkopf 117: 1 (1927).

10. Cole, P. Some aspects of temperature, moisture and heat relationship in upper respiratory tract. J. Laryng. and Otol. 67: 449 (1953).

11. Cramer, I. I. Heat and moisture exchange of respiratory mucous membrane. Ann. Otol. Thin. \& Laryng. 66: 327 (1957).

12. Déry, R., Pelletier, J., Jacques, A., Clavet, M., \& Houde, J.J. Humidity in anaesthesiology: II. Evolution of heat and moisture in the large carbon dioxide absorbers. Canad. Anaesth. Soc. J. 14: 205 (1967). 